\title{
RADIOIMMUNOASSAY OF LUTEINIZING HORMONE IN THE BLOOD OF ZEBU CATTLE
}

\author{
W. R. GARR* \\ Animal Productivity Research Laboratory, \\ National Council for Scientific Research, \\ P.O. Box 49, Chilanga, Zambia \\ (Received 3rd February 1971, accepted 11th May 1971)

\begin{abstract}
Summary. A solid-phase radioimmunoassay was used to measure LH in the serum of a Zebu cow and heifer during the oestrous cycle. Shortly after the onset of oestrus, serum levels of LH rose sharply to 20 to 120 $\mathrm{ng} / \mathrm{ml}$ before dropping to baseline levels of about $2 \mathrm{ng} / \mathrm{ml}$ after 8 to 10 hr. Elevated $\mathrm{LH}$ values were also detected in mid-cycle, although considerable variation in activity over several days occurred with the heifer. Peak values of $\mathrm{LH}$ were considerably higher in the serum of the cow than the heifer.
\end{abstract}

\section{INTRODUCTION}

The availability of sensitive and specific radioimmunoassay techniques has allowed the quantitative determination of many of the polypeptide hormones in the peripheral blood from a number of species of animals. Luteinizing hormone $(\mathbf{L H})$ in bovine plasma has been examined during the oestrous cycle by Schams \& Karg (1969a) and Niswender, Reichert, Midgley \& Nalbandov (1969). Schams \& Karg (1969b) have shown that the half-life of exogenous LH in bovine blood is about $35 \mathrm{~min}$, and that the endogenous release of LH is very short-lived. This quick clearance means that frequent blood samples are necessary to detect peaks of activity. Similar findings have been reported in respect of sheep blood during oestrus (Geschwind \& Dewey, 1968; Niswender et al., 1969; Goding, Catt, Brown, Kaltenbach, Cumming \& Mole, 1969).

Rakha \& Robertson (1965) investigated the timing of $\mathbf{L H}$ release from the pituitary gland during the bovine oestrous cycle. A significant drop in both the FSH and LH content of the pituitary was found to occur during a period of 0 to $18 \mathrm{hr}$ after the onset of oestrus. This suggested the release of the hormones into the blood stream. Schams \& Karg (1969a) confirmed this for LH and found that an LH peak in bovine serum could be demonstrated 15 to $22 \mathrm{hr}$ before ovulation. A further peak was shown to occur between Days 8 and 13 of the oestrous cycle, and it was sometimes possible to detect another, smaller peak 3 to 6 days before ovulation.

A preovulation peak has been detected by several workers in sheep serum,

* Present address: ARG Animal Breeding Research Organization, West Mains Road Edinburgh EH9 3JQ. 
although no other peaks have been reported during the oestrous cycle (Geschwind \& Dewey, 1968; Niswender et al., 1969; Goding et al., 1969).

The present investigation forms part of a study of the fertility of ranch cattle in Zambia. Earlier results (Agricultural Research Council of Central Africa Annual Report 1966/67) suggested that chronic starvation induces infertility by depression of pituitary gonadotrophic function but that indigenous Angoni (Zebu) cattle were less affected than introduced beef cattle.

Lamond (1970), in a review on the influence of undernutrition on reproduction in the cow, indicated that there is need for further investigation to understand the physiological basis as there is, at present, much speculation. It was therefore decided to study serum LH levels in Angoni cows during the oestrous cycle to establish the normal pattern.

\section{MATERIAL AND METHODS}

The experimental animals were a 5-year-old Angoni cow who had calved 10 months previously and was exhibiting regular oestrous cycles and an Angoni heifer. This breed is a short-horned Zebu type (Bos indicus) indigenous to the Eastern Province of Zambia. The heifer was 608 days old at the time of the first standing heat (cf. 591.2 $\pm 17 \cdot 3$ days-Rakha, Hale \& Igboeli, 1970). The experimental animals were provided with a feed supplying $12 \%$ crude protein at the rate of $1.8 \mathrm{~kg}$ daily, with free access to veld hay for the duration of the trial and were in good nutritional condition. They were maintained in a pen with a vasectomized bull and carefully observed. When oestrus was expected, a continuous watch was kept and blood was collected as soon as possible after observation of the first mating. Blood samples were collected at least once a day during the period of the trial, the frequency varying according to the time of the oestrous cycle. Samples from the heifer were collected a few days before the expected onset of the second oestrus and continued during oestrus at 30-min intervals, though during this period 2-hrly samples were usually sufficient. It was found advisable to bleed three times daily to establish the mid-cycle peak from Days 8 to 13 of the cycle. Blood samples were collected from the jugular veins using $20 \mathrm{ml}$ 'Vacutainers' (Becton-Dickinson, New Jersey, U.S.A.) with no anticoagulant. Serum was separated off and stored at $-20^{\circ} \mathrm{G}$ until the assay could take place. In all, 264 blood samples were collected and assayed.

Radioimmunoassays were carried out by the coated tube method, described by Goding et al. (1969), using small polystyrene disposable tubes. An equine antiserum to bovine LH was used to coat the tubes at a concentration of $1 / 7000$. Rabbit (anti-bovine $\mathrm{LH}$ ) antisera from two separate sources were also found to give comparable results. Radioiodination of the antigen was carried out by a modification of the method described by Greenwood, Hunter \& Glover (1963), using $5 \mu \mathrm{g}$ purified ovine LH (LER 1056 62) and $2 \mathrm{mCi}^{125} \mathrm{I}$ (Radiochemical Centre, Amersham. IMS3) to establish the method. A purified fraction from bovine pituitary glands prepared in these laboratories was iodinated in most assays and was found to have an immunological potency of 1.6 compared with NIH-LH-B6. The NIH standard was used throughout, and all results are expressed in terms of $\mathrm{ng} \mathrm{NIH}-\mathrm{LH}-\mathrm{B} 6 / \mathrm{ml}$ serum. 
Initially, the tubes were counted in a well-type scintillation counter but an auto-gamma-spectrometer, which became available during the experiment, was used latterly and found to give similar count ratios. The results were computed by converting the percentage of bound count of sample or standard to bound count of tube at zero concentration, i.e. B/Bo \% to Probit, and plotting the standard curve against the logarithm of the standard concentrations. This attempt to give linear expression to the dose-response curves was not entirely successful, as can be seen by examination of Text-fig. 1 which is an example of a typical standard curve. These curves were satisfactory over the range 0.75 to $10 \mathrm{ng} / \mathrm{ml}$. All samples and standards were run in quadruplicate, and a

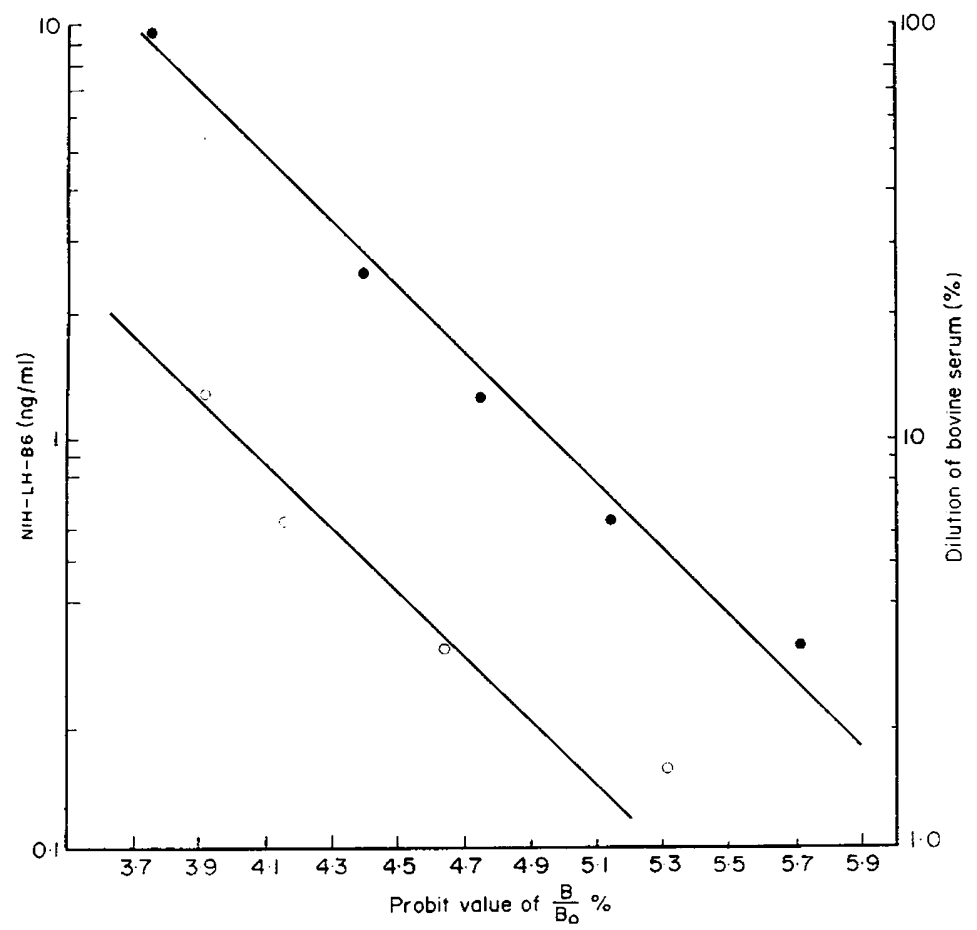

TExT-FIG. 1. Standard curve of radioimmunoassay for bovine LH in phosphate buffer containing bovine serum albumin and the effect of dilution on a serum sample rich in endogenous LH. $\bigcirc$, Bovine serum; O NLH-LH-B6 Standard.

standard curve was prepared for each assay. The specificity was checked by examination of the standard curve and both the donated LH and the Carr LH were found to have the same slope as NIH-LH-B6 and to be of similar immunological potency. Dilutions of bovine serum containing high endogenous LH gave a similar slope to the standard curve (Text-fig. 1). Pooled low LH serum with added purified LH gave a similar slope although, at levels higher than those shown, a steeper curve than the standard's was obtained. This appears similar to the effect with growth hormone, reported by Purchas, MacMillan \& Hafs (1970). As LH-free serum was not available to use with the standards and blanks, all sera with high endogenous LH were diluted until the levels fell within the working portion of the standard curve, i.e. less than $10 \mathrm{ng} / \mathrm{ml}$. The 
remaining sera were found to give the most reproducible results at a dilution of $25 \%$ with a bovine serum albumin (BSA) buffer diluent.

A sample of NIH-FSH-S5 was assayed by this technique and was found to give a relative potency of 0.006 NIH-LH-B 6 units/mg. This appears to be similar to the contamination with LH reported by the Endocrinology Study Section of the National Institutes of Health. The assay, however, was not species-specific. Satisfactory cross-reaction was obtained with pituitary extracts from a number of different wild ungulates.

\section{RESULTS}

Serum LH levels of blood samples collected from the Angoni heifer during two standing oestrous periods are shown in Text-fig. 2. It will be noted that a

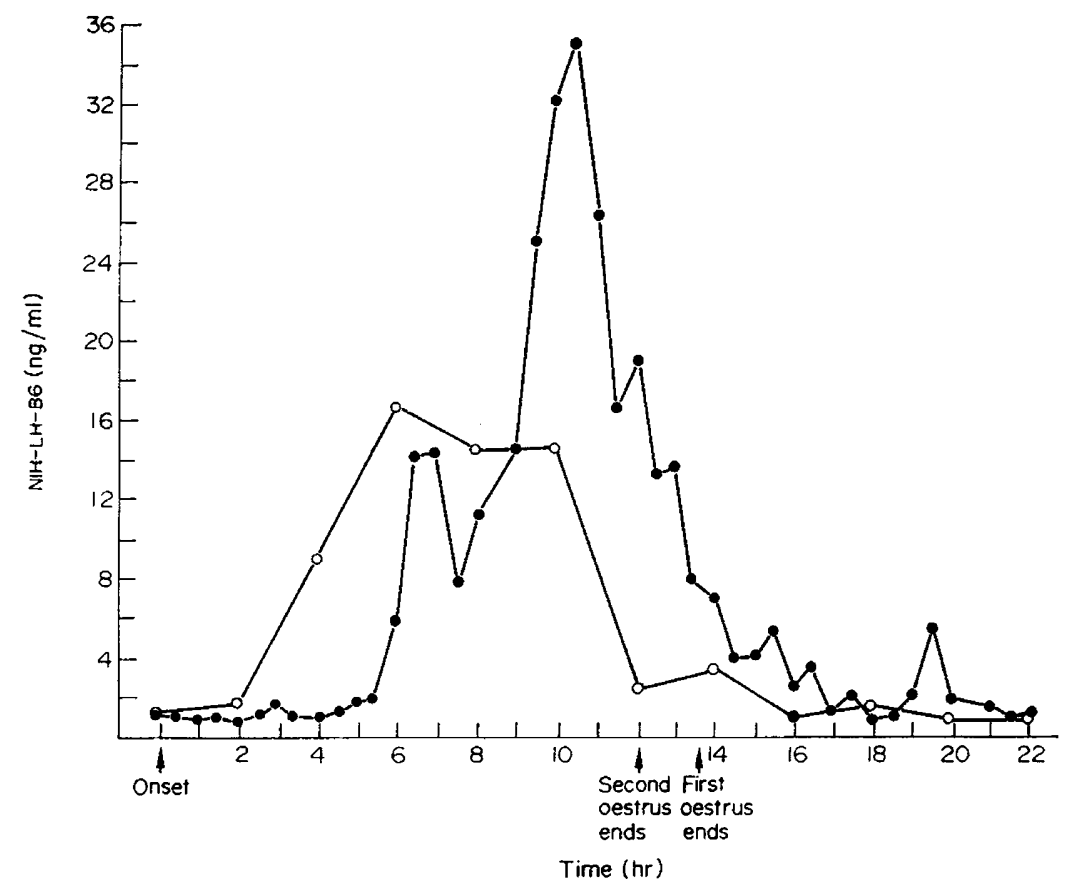

TEXT-FIG. 2. Changes in serum LH occurring during two successive standing oestrous periods ( $)$, first; $O$, second) in an Angoni heifer.

possible peak value could have been missed in the second case, when the samples were collected at 2-hrly intervals. The corresponding levels from samples collected from the Angoni cow are shown in Text-fig. 3. There was some doubt about the exact time of onset of oestrus in this case, which may explain why the peak values appear to occur earlier. The peak levels of $\mathbf{L H}$ for the cow are considerably higher than those for the heifer.

The LH levels for the whole oestrus cycle are shown in Text-fig. 4 for the heifer, and Text-fig. 5 for the cow. In the former, the variations in levels seen between Days 8 and 13 were repeated after the following oestrus, but at a 


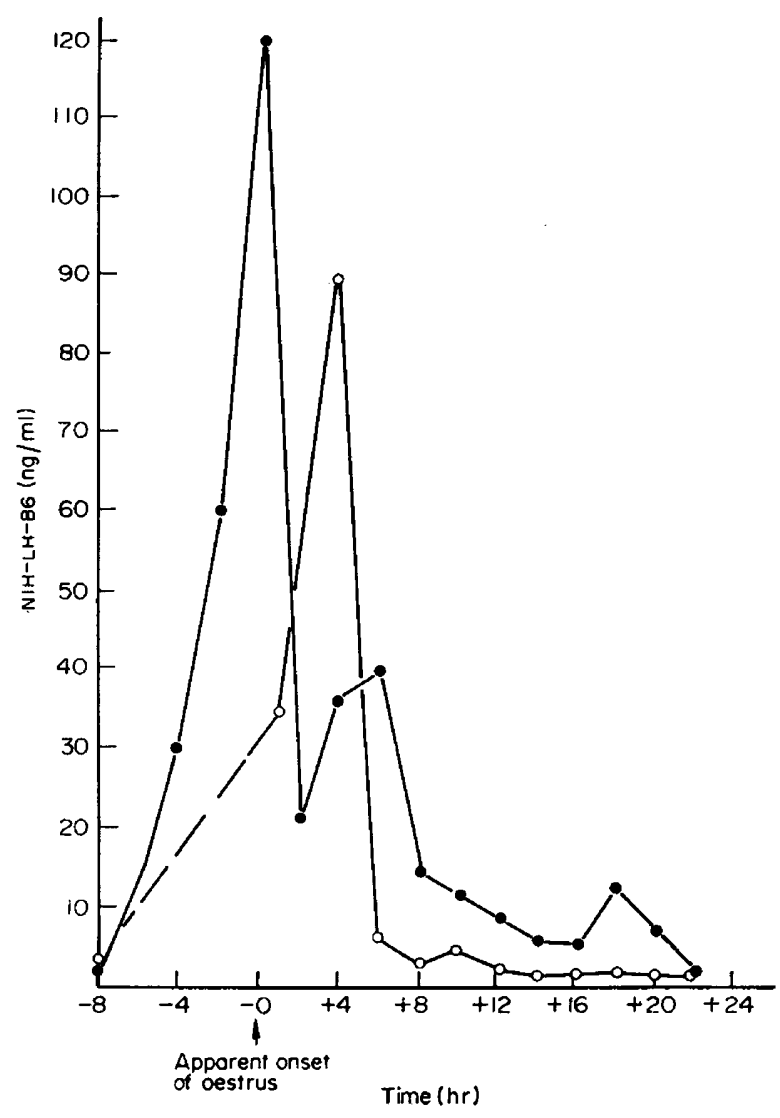

Text-Fic. 3. LH levels in the serum of an Angoni cow during two successive standing oestrous periods ( $\bullet$, first; $O$, second).

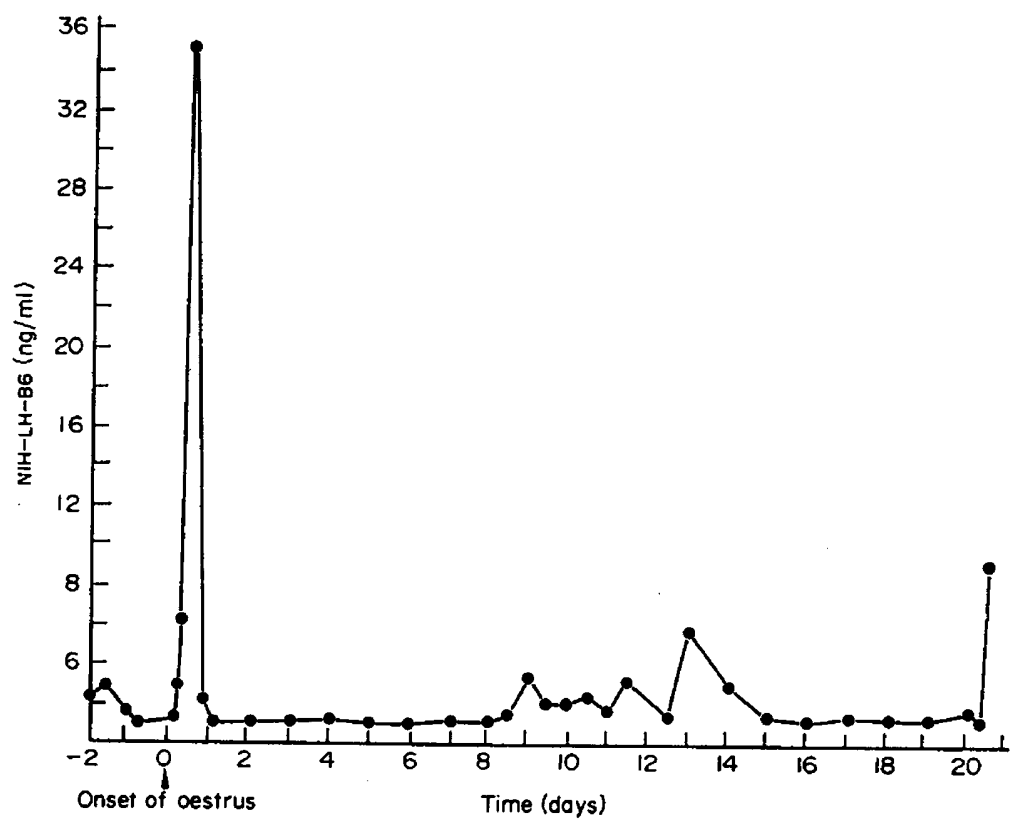

TrxT-FIG. 4. Changes in serum LF occurring during the oestrous cycle of an Angoni heifer. 
higher level. The cow demonstrated a somewhat different pattern of one sharp peak on Day 16 of the cycle, which was 28 days in length. No other elevation of levels was detected although, in some cases, a slight increase was seen immediately before oestrus.

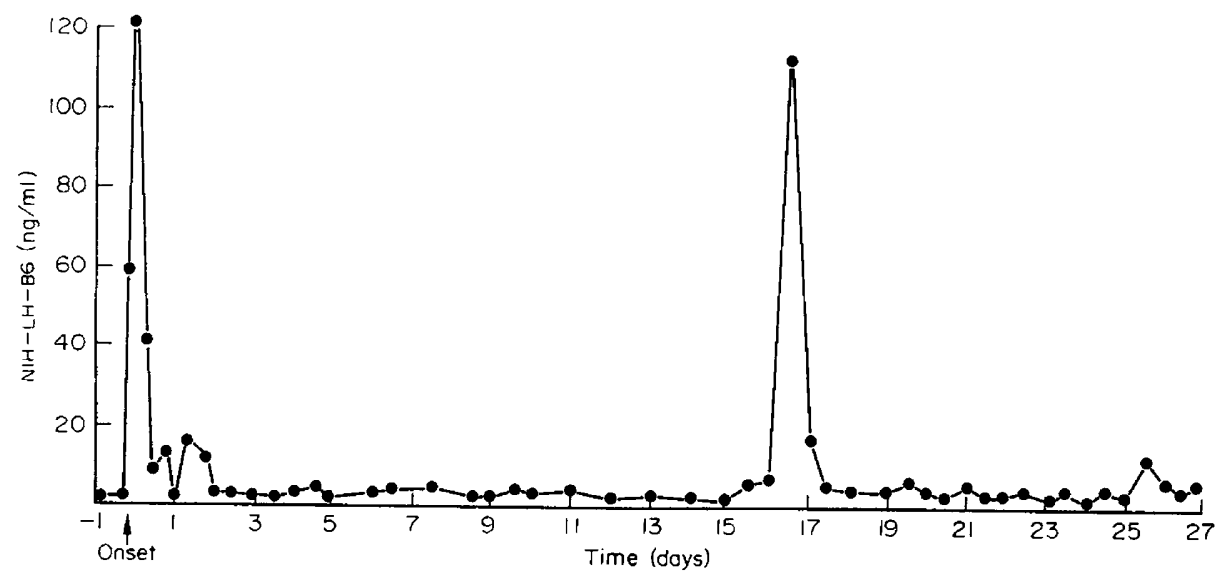

TeXT-FIG. 5. Changes in serum LH occurring during the oestrous cycle of an Angoni cow.

\section{DISCUSSION}

The extremely sharp and short-lived nature of the secretion of $\mathrm{LH}$ gives rise to some doubt whether all peak values can be established unless samples are taken at 4-hrly intervals, although 12-hrly intervals should give an indication. As many samples were collected daily, it is possible that some peaks were missed. During standing oestrus, bleeding intervals must be reduced to $2 \mathrm{hr}$, at most, to be certain of detecting maximum LH values. In the Angoni heifer, the onset and end of the oestrous period were much more clear-cut than with the cow, and the sharp drop from peak $\mathrm{LH}$ values corresponded with the end of the period.

The general pattern of results was very similar to that obtained by Schams \& Karg (1969a), although the peak levels obtained were considerably higher. This could have been due to assay differences. Buckler \& Clayton (1970) point out the dangers of comparing results from different workers, due to the enormous variation in the techniques and materials. Qualitatively at least, there appears to be little difference between Bos taurus and Bos indicus, although the quantitative changes and differences between the breeds occurring as a result of nutritional stress under extensive ranching conditions may be of considerable importance to fertility.

Rakha, Igboeli \& Hale (1970) showed that Angoni cattle have a mean oestrous cycle length of 21.9 days, with an oestrous period of $16.3 \mathrm{hr}$. The time of onset was usually at sunset or sunrise, and ovulation occurred $31.5 \mathrm{hr}$ after onset. The main LH preovulatory peak, therefore, occurs about $20 \mathrm{hr}$ before ovulation. The intensity of oestrus was low in the cow, although a high maximum LH concentration of $120 \mathrm{ng} / \mathrm{ml}$ was obtained, and the exact beginning 
and end of the period was difficult to establish. In the heifer, on the other hand, with a maximum level of $35 \mathrm{ng} / \mathrm{ml}$, the beginning and end of oestrus was simple to establish and it was noted that the end of oestrus occurred when LH had dropped to low levels (see Text-fig. 2).

The mid-cycle peak shown in the serum from the cow gave a maximum value which would have been missed with once daily bleedings. It occurred 11 days before the onset of the next oestrous period in an abnormally long cycle and had about the same LH potency as the preovulatory peak. In the heifer, there was considerable variation in $\mathbf{L H}$ activity at a relatively low level over several days, and a similar effect was obtained during the subsequent cycle. This was possibly associated with an incomplete neurohumoral mechanism due to the age of the animal. The gonadotrophin peak occurred at the stage of the oestrous cycle when cervical dilatation can be seen (Rakha et al., 1970) and at the point of atresia of the largest follicle (Bane \& Rajakoski, 1961).

Both baseline and peak serum LH concentrations of ruminants at different stages of the oestrous cycle require further investigation, both between breeds and between animals, as it is reasonable to expect that these will be related to fertility. As a tool for this, the radioimmunoassay technique shows great promise. The measurement of a number of anterior pituitary hormones in blood is now possible and a greater insight into the effect of environment, nutrition and breed on fertility of ranch cattle should be feasible.

\section{AGKNOWLEDGMENTS}

This work was supported by Research Contract Programme No. 799/RB from the International Atomic Energy Agency. Rabbit (anti-bovine LH) antiserum was kindly provided by Professor H. Karg, rabbit (anti-ovine LH) antiserum by Dr G. D. Niswender, equine (anti-bovine LH) antiserum by Dr R. Snook, purified ovine LH (LER 1056 62) by Dr L. E. Reichert, and NIH-LH-B6 by the National Institutes of Health, Bethesda, Maryland, U.S.A. I am grateful to Mr J. Parshotam, Mr A. Nkhoma and Mr G. Mateyo for technical assistance, and to $\mathrm{Mr}$ J. Marr for undertaking the isotope counting.

\section{REFERENCES}

Agricultural Research Council of Central Afriga. Annual Report 1966/1967, Salisbury, Rhodesia. Bane, A. \& Rajakoski, E. (1961) The bovine estrous cycle. Cornell Vet. 51, 77.

BuckLER, J. M. H. \& Clayton, B. E. (1970) Studies on the specificity of the radioimmunoassay of luteinizing hormone. Acta endocr., Copenh. 63, 545.

Geschwind, I. I. \& DEwey, R. (1968) Dynamics of luteinizing hormone (IH) secretion in the cycling ewe: a radioimmunoassay study. Proc. Soc. exp. Biol. Med. 129, 451.

Goding, J. R., Gatt, K. J., Brown, J. M., Kaltenbagh, C. C., Cumming, I. A. \& Mole, B. J. (1969) Radioimmunoassay for ovine luteinizing hormone during estrus and following estrogen administration in the sheep. Endocrinology, 85, 133.

Greenwood, F. G., Hunter, W. M. \& Glover, J. S. (1963) The preparation of ${ }^{131}$ I-labelled human growth hormone of high specific radioactivity. Biochem. 7. 89, 114.

LAMOND, D. R. (1970) The influence of undernutrition on reproduction in the cow. Anim. Breed. Abstr. 38, 359.

Niswender, G. D., Reighert, L. E., Midgley, A. R. \& Nalbandov, A. V. (1969) Radioimmunoassay for bovine and ovine luteinizing hormone. Endocrinology, 84, 1166. 
Purchas, R. W., Macmillan, K. L. \& Hafs, H. D. (1970) Pituitary and plasma growth hormone levels in bulls from birth to one year of age. $\mathcal{7}$. Anim. Sci. 31, 358.

Rakha, A. M., Hale, D. \& IgBoeli, G. (1970) The age of puberty in local breeds of cattle in Central Africa. 7. Reprod. Fert. 22, 369.

Rakha, A. M., Igboeli, G. \& Hale, D. H. (1970) The oestrus cycle of Zebu and Sanga breeds of cattle in Central Africa. 7. Reprod. Fert. 23, 411.

RAKha, A. M. \& Robertson, H. A. (1965) Changes in levels of follicle stimulating hormone and luteinizing hormone in the bovine pituitary gland at ovulation. 7. Endocr. 31, 245.

Schams, D. \& KARG, H. (1969a) Radioimmunologische LH-Bestimmung im Blutserum vom Rind unter Besonderer Berücksichtigung des Brunstzyklus. Acta endocr., Copenh. 61, 96.

Schams, D. \& KARG, H. (1969b) Zeitlicher Verlauf und analytische Erfassbarkeit des endogen beim exogen erhöhten Blutspiegels an Luteinisierungshormon beim Rind. Zuchthygiene, 4, 61 . 